\title{
INDIGENOUS RHIZOBACTERIA SCREENING FROM TOMATO TO CONTROL Ralstonia syzigii subsp. Indonesiensis AND PROMOTE PLANT GROWTH RATE AND YIELD
}

\author{
Yulmira Yanti, Hasmiandy Hamid, \& Reflin \\ Department of Plant Protection, Faculty of Agriculture, Andalas University, Padang \\ West Sumatra, Indonesia 25163 \\ Email:mira23@agr.unand.ac.id
}

\begin{abstract}
Indigenous rhizobacteria screening from tomato to control Ralstonia syzigii subsp. indonesiensis and promote plant growth rate and yield. Bacterial wilt is the most damaging vascular pathogen on tomato and many other crops in tropical, subtropical and warm temperate areas of the world which limits the production. Rhizobacteria have been concerned as potential biological control agents due to their ability to promote plant growth and health, and their role as antagonists of plant pathogens. The purpose of this research was to screen the best indigenous rhizobacteria (IRB) that able to control bacterial wilt disease and increase growth rate and yield of tomato plant. This research was conducted in 3 stages: (1) Isolation and selection of indigenous rhizobacteria as PGPR on tomato seedlings, consisted of 27 IRB isolates and a control, with triplications; (2) Selection of IRB isolates that control R. syzigii subsp. indonesiensis on tomato plants, which consisted of 8 treatments including 7 IRB and a control with 5 replications; (3) Characterization of IRB isolates ability to promote plant growth (indicated with IAA production \& phosphate solubilizing). The variables observed were disease development, growth enhancement and IRB isolate ability to produce IAA and solubilize phosphate. The results showed that all IRB isolates were able to control bacterial wilt disease and increase the growth rate and yield of tomato. IR2.3.5, IR1.3.4 and IR1.4.2 were the best isolates in controlling $R$. syzigii subsp. indonesiensis and increasing the growth rate and yield by $81.25 \%$ and $68.72 \%$ respectively. All isolates showed various abilities to produce IAA, however, only isolates IR2.3.5 and IR1.3.4 that had abilities to solubilize phosphate.
\end{abstract}

Keywords: biocontrol agents, IAA, in planta technique, PGPR

\begin{abstract}
ABSTRAK
Seleksi rizobakteri indigenos dari tomat untuk pengendalian Ralstonia syzigii subsp. indonesiensis dan Pemacu pertumbuhan dan hasil. Penyakit layu bakteri merupakan penyakit vaslular yang paling merugikan bagi tanaman tomat dan berbagai tanaman lain di wilayah tropis, subtropis dan wilayah bersuhu hangat di dunia dan membatasi produksinya. Rizobakteri telah diketahui sebagai agens biokontrol karena kemampuannya dalam memacu pertumbuhan dan kesehatan tanaman serta perannya sebagai agens antagonis terhadap patogen tanaman. Penelitian ini bertujuan untuk menyeleksi rizobakteri indigenos (IRB) terbaik yang mampu mengendalikan penyakit layu bakteri dan meningkatkan pertumbuhan dan hasil tanaman tomat. Penelitian ini terdiri atas 3 tahap: (1) isolasi dan seleksi IRB sebagai PGPR pada perkecambahan tomat, terdiri dari 27 isolat IRB dan kontrol dengan 3 ulangan; (2) seleksi isolat IRB untuk pengendalian R. syzigii subsp. indonesiensis pada tanaman tomat, terdiri dari 8 perlakuan termasuk 7 isolat IRB dan kontrol dengan 5 ulangan; (3) karakterisasi kemampuan isolat IRB dalam memacu pertumbuhan (ditunjukkan dengan produksi IAA dan kemampuan melarutkan fosfat). Variabel yang diamati yaitu perkembangan penyakit, peningkatan pertumbuhan dan kemampuan isolat IRB untuk memproduksi IAA dan melarutkan fosfat. Hasil menunjukkan bahwa semua isolat IRB mampu mengendalikan penyakit layu bakteri dan meningkatkan pertumbuhan dan hasil tomat. IR2.3.5, IR1.3.4 dan IR1.4.2 adalah isolat terbaik dalam mengendalikan $R$. syzigii subsp. indonesiensis dan meningkatkan pertumbuhan dan hasil secara berturut-turut $81,25 \%$ dan $68,72 \%$. Semua isolat menunjukkan kemampuan yang beragam dalam memproduksi IAA, namun hanya isolat IR.2.3.5 dan IR1.3.4 yang mampu melarutkan fosfat.
\end{abstract}

Kata kunci: agens biokontrol, IAA, PGPR, teknik in planta 


\section{INTRODUCTION}

Ralstonia syzigii subsp. indonesiensis (Safni et al., 2014), previously named Ralstonia solanacearum phylotype IV, is a soil-borne gram-negative bacterium that causes bacterial wilt disease in over 200 families of plants, including tomatoes (Anith et al., 2004; TansKersten et al., 2001). This pathogen causes wilt by infecting plants through roots and colonizing stem vascular tissue and the vascular tissues in the lower stem of the wilted plants usually show a brown discoloration (Pradhanang et al., 2003). Approximately 450 crop species were reported as hosts of Ralstonia (Swanson et al., 2005). Attention has been paid to minimize the disease infestation through cultural practices, development of resistant varieties and use of chemicals, but most of them have a limited success (Maji \& Chakrabartty, 2014). Bacterial wilt management in tomato and in other crops has been difficult. Even though integrated management, including cultural practices, crop rotation, and use of resistant cultivars, provides some limited success, the disease still threatens commercial tomatoes (Kucharek, 1998).

Biological control has emerged as one of the important methods in the management of soilborne plant pathogens. Biological control reduces the dependence on high-risk chemicals for disease management and is ecologically sound and environmentally friendly technique (Bowen \& Rovira, 1999; Whipps, 1997). Plant growth promoting rhizobacteria (PGPR) are potential agents for biological control of plant pathogens (Kloepper et al., 1999). PGPR bring about disease suppression by various modes of action such as antagonism, competition for space and nutrients, and induction of systemic resistance (Kloepper et al., 1999; Zehnder et al., 2001).

Plant growth promoting activity by rhizobacteria may be associated with secretion of auxins, gibberellins, and cytokinins (Ramamoorthy \& Samiyappn, 2001) and suppression of deleterious microorganisms in the rhizosphere (Gamliel \& Katan, 1993). The use of rhizosphere bacteria for increasing yield and for crop protection is an attractive approach in the modern system in developing a sustainable agriculture. PGPR are also known to rapidly colonize the rhizosphere and suppress deleterious microorganisms as well as soilborne pathogens at the root surface (Rangajaran et al., 2003). These organisms can also be beneficial to the plants by stimulating growth (Bloemberg \& Lugtenberg, 2001).

PGPR are antagonistic to the pathogens and incorporate them into successful disease management as biocontrol agents. A key feature of such organisms is their ability to adjust to the rhizosphere and to aggressively colonize the host roots (Dunne et al., 1997). Therefore, it was recommended that to achieve greater efficiency of biocontrol agents they should be isolated from the environment where they would be required to function (Cook, 1993). Bacillus spp. provided complete control of black rot on crucifer (Ahmad et al., 2006). In greenhouse studies, E. herbicola and Bacillus subtilis suppressed $X$. axonopodis pv. vignicola on cowpea and $X$. axonopodis pv. vignearandiatae on mungbean (Falcon-Rodríguez et al., 2009; Fry, 1987). Some of the microorganisms antagonistic to $R$. solanacearum are Bacillus species and Pseudomonas fluorescens (Anuratha \& Gnanamanickam, 1990; Xue et al., 2009), Stenotrophomonas maltophilia (Messiha et al., 2007), Streptomyces setonii (Lemessa \& Zeller, 2007).

Therefore, the research was purposed to acquire best indigenous rhizobacteria which are able to control bacterial wilt disease and increase growth rate and yield of tomatoes.

\section{MATERIALS AND METHODS}

Research Site. This research was conducted in Laboratory of Microbiology, Department of Plant Protection, and in Greenhouse, Faculty of Agriculture, Andalas University, Padang, Indonesia from November 2017 to May 2018.

Procedures. This research consisted of 3 stages; i.e. (1) isolation and selection of Indigenous rhizobacteria (IRB) as PGPR in seedlings which consisted of 28 treatments (27 IRB and 1 control) with triplications; (2) Selections of IRB isolates antagonistic to $R$. syzigii subsp. indonesiensis in tomato seedlings which consisted of 8 treatments ( 7 selected IRB from previous stage and inoculated control plants) with 5 replications; (3) Characterization of best IRB isolates (from previous stage) ability to promote growth, indicated with IAA IAA production and Phosphate solubilizing. All experiments were arranged in the completely randomized design.

Isolation and selection of Indigenous Rhizobacteria (IRB) as PGPR in seedlings Isolation of Indigenous rhizobacteria from tomatoes' rhizosphere. IRB samples were isolated from rhizosphere of healthy tomatoes grown in Ralstonia wilt endemic areas in Solok, Tanah Datar and Agam District, Province of West Sumatera, Indonesia. The method of Yanti et al. (2017) was applied. The suspensions of the rhizospheric soil samples were serially diluted to 10-5 and 10-6, and spread onto NA medium, incubated at 27 
${ }^{\circ} \mathrm{C}$ for 48 hours. Morphologically dominant and different form of colonies were selected. The selected bacterial colonies were purified in the same medium and incubated at $27^{\circ} \mathrm{C}$ for 48 hours. Each single colony of bacteria was then transferred aseptically to a microtube containing $1 \mathrm{~mL}$ of sterile aquadest, and stored in refrigerator for further use.

Reculturing Isolates. A single pure colony of IRB was added into $25 \mathrm{~mL}$ of NB in culture bottle $(50 \mathrm{~mL})$ and incubated in rotary shaker at $27^{\circ} \mathrm{C}$ for 24 hours. One $\mathrm{mL}$ preculture was transferred into $150 \mathrm{~mL}$ of sterile coconut water in Erlenmeyer flask for main cultures and incubated at $27^{\circ} \mathrm{C}$ for 48 hours (Yanti et al., 2017). Suspension of rhizobacteria from main cultures was diluted with comparison to McFarland scale 8 (Density estimated $10^{8} \mathrm{CFU} / \mathrm{mL}$ ).

PGPR Assay in Seedlings. Tomato seeds used were Warani variety (susceptible to bacterial wilt disease). Seeds were sterilized before used with consecutively sterilized aquadest, $\mathrm{NaOCl} 1 \%$, three times rinsed with sterilized water each for 2 minutes and then air-dried. Sterilized tomato seeds were dipped into IRB suspensions and the controls were dipped into sterilized aquadest for 10 minutes and planted to pot-tray containing sterilized soil and cow dung manure mixture $(2: 1 \mathrm{v} / \mathrm{v})$. Each treatment used 25 seeds. Nurseries were conducted in 3 weeks with parameter observed including germination rate ((seeds grow/total seeds)*100\%), seedlings' height and number of leaves.

Selections of IRB isolates to control $R$. syzigii subsp. indonesiensis. All tomato seedlings from previous stage ( 3 weeks old) were planted onto polybags containing the same soil mixtures, and reintroduced with IRB isolates by dipping them in the IRB suspensions for 15 minutes. The control seedlings were only inoculated with pathogen, without IRB treatment.

Pathogen R. syzigii subsp. indonesiensis was isolated directly from symptomatically diseased tomato stem. Bacterial mass were taken out from stem by cutting the stem base, surface sterilized and dipping it into sterilized aquadest. Bacterial masses was streaked onto Tetrazolium Chloride (TZC) medium and incubated at $27{ }^{\circ} \mathrm{C}$ for 48 hours. The virulent colonies were characterized based on Hayward (1985) method. The virulent isolate was streaked onto the same medium and incubated for 48 hours. The colony then suspensed with sterilized water and its density was set to $10^{7} \mathrm{CFU} /$ $\mathrm{mL}$ (compared with McFarland scale 7). The pathogen was inoculated at 2 weeks after planting by cutting roots at 2 sides of the plant, and then $30 \mathrm{~mL}$ of pathogen suspension was poured into the tomato root zone. The variables observed included disease development time, disease incidence ((plant diseased/total plants)*100\%), disease severity (daily observed since pathogen inoculation, A 5 point visual scale, 0 being undamaged and 4 being completely wilted, was used for recording disease development as adopted by Kelman \& Person (1961)), and tomato plant growth including plant height and number of leaves (weekly observed), first flowering (daily observed) and yield (summarized at the end of observation).

Characterization of IRB isolates ability Indole Acetic Acid (IAA) Production. IAA production was quantitatively analyzed by the method of Patten \& Glick (2002). Spectroscopic analysis was performed at 520 $\mathrm{nm}$ and quantified using a tryptophan standard curve. IRB was grown in $2.000 \mathrm{ml} \mathrm{NB}$ with and without $0.5 \mathrm{~g} /$ $\mathrm{L}$ tryptophan (precursor of IAA) in darkness for 3 days at $28^{\circ} \mathrm{C}$ at $110 \mathrm{rpm}$. Bacterial culture suspensions were centrifuged $(30 \mathrm{~min}$ at $3.220 \times \mathrm{g}$ ) and $0.2 \mathrm{ml}$ of the super-natant was mixed with $1 \mathrm{ml}$ Salkowski's reagent $(50 \mathrm{ml} 35 \% \mathrm{HClO} 4,1 \mathrm{ml} 0.5 \mathrm{MFeCl} 3)$. After $30 \mathrm{~min}$, a pink color was developed, which indicated IAA production. The absorbance of pink color was read at $530 \mathrm{~nm}$ using a spectrophotometer. The IAA concentration was determined using a calibration curve of pure IAA as a standard following the linear regression analysis.

Phosphate Solubilizing. The ability of the isolates to solubilize tri-calcium phosphate was observed according to Wahyudi et al. (2011). Isolates of IRB were inoculated onto Pikovskaya's Agar and incubated at $36 \pm 2{ }^{\circ} \mathrm{C}$ for five days. Formation of halo indicated phosphate solubilizing.

\section{RESULTS AND DISCUSSION}

Our study obtained 27 IRB isolated from rhizosphere of healthy tomatoes from Solok, Agam and Tanah Datar Regency. Those isolates were screened to acquire best isolates as growth promoter. Introduction of IRB Isolates by dipping method could increase the seed germination ability compare to control (Table 1). Half of isolates could increase field germinability, height and number of leaves of tomato seedling better than controls.

The results showed that isolates IR.2.3.5, IR.2.2.7, IR.1.3.4, IR.3.1.4, IR.2.2.1, IR.3.1.2, IR.2.2.6, and IR.2.2.5 were the best isolates in promoting tomato 
seedlings growth. Those isolates were used for further experiments.

Introduction of IRB isolates decreased the disease development time, incidence and severity (Table 2). Five isolates of IRB decreased the disease incidence up to $0 \%$ and caused no wilt symptoms until the end of observations at 42 days after pathogen inoculation, compared to control $(100 \%)$. Introduction of IRB isolates also promoted plant growth after inoculation of pathogen. Isolates IR.2.3.5, IR.1.3.4, IR.3.1.4, IR.2.2.1 and IR.2.2.7 had the highest ability to promote growth of tomatoes and could also suppress the pathogen, indicated with no disease symptoms at the last day of observation.

Our further studies showed that six of seven IRB isolates assayed in this study were able to promote growth and yield of tomato not only on seedlings stage, but also until generative phase. Unfortunately, not all of selected IRB isolates could accelerate flowering phase and increase yield of tomato. The yield increased on six of seven isolates of IRB compared to control (Table 3). The yield of treatments with IRB varied from 1.8307 to $1.252 \mathrm{~kg}$, higher than control $(1.01 \mathrm{~kg})$.

Table 1. Seed germination, seedlings height and number of leaves at 21 days after IRB application

\begin{tabular}{|c|c|c|c|c|c|c|}
\hline Isolates & $\begin{array}{c}\text { Seed } \\
\text { Germination } \\
(\%)\end{array}$ & $\begin{array}{l}\text { Effectivene } \\
\text { ss }(\%)\end{array}$ & $\begin{array}{l}\text { Seedlings } \\
\text { height }(\mathrm{cm})\end{array}$ & $\begin{array}{c}\text { Effectiveness } \\
(\%)\end{array}$ & $\begin{array}{l}\text { No. of } \\
\text { leaves }\end{array}$ & $\begin{array}{c}\text { Effectiveness } \\
(\%)\end{array}$ \\
\hline IR.2.3.5 & 96.67 & 31.81 & $9.76 \mathrm{a}$ & 25.13 & $4.00 \mathrm{a}$ & 11.11 \\
\hline IR.2.2.7 & 96.67 & 31.81 & $9.73 \mathrm{a}$ & 24.74 & $4.00 \mathrm{a}$ & 11.11 \\
\hline IR.1.3.4 & 93.33 & 27.26 & $9.72 \mathrm{a}$ & 24.61 & $4.00 \mathrm{a}$ & 11.11 \\
\hline IR.3.1.4 & 93.33 & 27.26 & $9.45 \mathrm{ab}$ & 21.15 & $4.00 \mathrm{a}$ & 11.11 \\
\hline IR.2.2.1 & 90.00 & 22.72 & $9.12 \mathrm{abc}$ & 16.92 & $4.00 \mathrm{a}$ & 11.11 \\
\hline IR.3.1.2 & 90.00 & 22.72 & $8.90 \mathrm{abc}$ & 14.10 & $4.00 \mathrm{a}$ & 11.11 \\
\hline IR.2.2.6 & 86.67 & 28.17 & $8.75 \mathrm{abc}$ & 12.18 & $4.00 \mathrm{a}$ & 11.11 \\
\hline IR.2.2.5 & 86.67 & 18.17 & $7.94 \mathrm{abcd}$ & 1.79 & $3.60 \mathrm{ab}$ & 0.00 \\
\hline Control & 73.34 & - & $7.80 \mathrm{abcd}$ & & $3.60 \mathrm{ab}$ & - \\
\hline IR.1.3.1 & 76.67 & 4.54 & 7.49 abcde & -3.97 & $3.20 \mathrm{abc}$ & -11.11 \\
\hline IR.1.1.1 & 70.00 & -4.55 & 6.99 abcdef & -10.38 & $3.20 \mathrm{abc}$ & -11.11 \\
\hline IR.1.1.2 & 70.00 & -4.55 & 6.97 abcdef & -10.64 & $2.80 \mathrm{abcd}$ & -22.22 \\
\hline IR.1.1.3 & 63.34 & -13.63 & $6.46 \mathrm{cdefg}$ & -17.18 & $2.80 \mathrm{abcd}$ & -22.22 \\
\hline IR.2.3.1 & 60.00 & -18.19 & $6.28 \mathrm{cdefg}$ & -19.49 & $2.80 \mathrm{abcd}$ & -22.22 \\
\hline IR.3.1.5 & 56.67 & -22.73 & $6.17 \mathrm{cdefg}$ & -20.89 & $2.80 \mathrm{abcd}$ & -22.22 \\
\hline IR.3.1.7 & 50.00 & -31.82 & 5.50 defgh & -29.49 & $2.80 \mathrm{abcd}$ & -22.22 \\
\hline IR.2.1.6 & 50.00 & -31.82 & 5.39 defgh & -30.89 & $2.40 \mathrm{bcd}$ & -33.33 \\
\hline IR.2.3.2 & 46.67 & -36.36 & 5.14 defgh & -34.10 & $2.40 \mathrm{bcd}$ & -33.33 \\
\hline IR.2.3.3 & 46.67 & -36.36 & $4.43 \mathrm{efgh}$ & -43.20 & $2.00 \mathrm{~cd}$ & -44.44 \\
\hline IR.2.3.4 & 46.67 & -36.36 & $4.36 \mathrm{efgh}$ & -44.10 & $2.00 \mathrm{~cd}$ & -44.44 \\
\hline IR.2.3.1 & 40.00 & -45.46 & $4.13 \mathrm{fgh}$ & -47.05 & $2.00 \mathrm{~cd}$ & -44.44 \\
\hline IR.1.2.1 & 36.67 & -50.00 & $3.98 \mathrm{fgh}$ & -48.97 & $1.80 \mathrm{~cd}$ & -50.00 \\
\hline IR.1.3.2 & 36.67 & -50.00 & $3.94 \mathrm{fgh}$ & -49.49 & $1.80 \mathrm{~cd}$ & -50.00 \\
\hline IR.1.2.2 & 33.34 & -54.54 & $3.78 \mathrm{gh}$ & -51.54 & $1.80 \mathrm{~cd}$ & -50.00 \\
\hline IR.3.2.4 & 30.00 & -59.09 & $3.58 \mathrm{gh}$ & -54.10 & $1.60 \mathrm{~d}$ & -55.55 \\
\hline IR.1.2.3 & 30.00 & -59.09 & $3.58 \mathrm{gh}$ & -54.10 & $1.40 \mathrm{~d}$ & -61.11 \\
\hline IR.3.1.3 & 30.00 & -59.09 & $3.58 \mathrm{gh}$ & -54.10 & $1.60 \mathrm{~d}$ & -55.55 \\
\hline IR.2.1.5 & 30.00 & -59.09 & $2.82 \mathrm{~h}$ & -63.85 & $1.40 \mathrm{~d}$ & -61.11 \\
\hline
\end{tabular}

Note: Means with the same letter at the same column are not significantly different by Duncan multiple range test at $\mathrm{p}<0.05$ 
Production of indole acetic acid (IAA) by all selected IRB isolates was detected by the production of pink colour for all isolates. Production of IAA was not dependent on the presence of tryptophan even though highest concentration was read from IRB isolates to which tryptophan had been added. All IRB isolates produced IAA when grown in media containing tryptophan which is obvious by the production of pink colour by all isolates (Table 4). Using spectrophotometer (Thermo Spectronic, Merck, SA), absorbance at 535 $\mathrm{nm}$. It was revealed that isolate IR.2.3.5 had the highest IAA production (32.54 ppm) while IR.2.2.6 had the lowest IAA production (18.7 ppm). Qualitatively phosphate solubilizing was detected on Pikovskaya agar plate, evident by halo around the inoculated spot. Only isolates IR.2.3.5 and IR.1.3.4 showed positive results. The other isolates were negative without any clear zones.

Results of our studies showed that applications of IRB are an important factor that could enhance biological control activities. Increased colonization of the emerging roots by the biocontrol agents, which also serve as the major port of entry of the bacterial pathogen, might have prevented R. syzigii subsp. indonesiensis from entering the host. Root colonization by biocontrol

Table 2. Incubation period, disease incidence, and disease severity on tomato plants

\begin{tabular}{ccccccc}
\hline Isolates & $\begin{array}{c}\text { Disease } \\
\text { incubation } \\
(\text { day) }\end{array}$ & $\begin{array}{c}\text { Effective- } \\
\text { ness (\%) }\end{array}$ & $\begin{array}{c}\text { Disease Incidence } \\
(\%)\end{array}$ & $\begin{array}{c}\text { Effective- } \\
\text { ness } \\
(\%)\end{array}$ & $\begin{array}{c}\text { Disease } \\
\text { severity }\end{array}$ & $\begin{array}{c}\text { Effective- } \\
\text { ness } \\
(\%)\end{array}$ \\
\hline IR.2.3.5 & $42.00^{*}$ & 133.33 & 0.00 & 100.00 & 0.00 & 100.00 \\
IR.1.3.4 & $42.00^{*}$ & 133.33 & 0.00 & 100.00 & 0.00 & 100.00 \\
IR.3.1.4 & $42.00^{*}$ & 133.33 & 0.00 & 100.00 & 0.00 & 100.00 \\
IR.2.2.1 & $42.00^{*}$ & 133.33 & 0.00 & 100.00 & 0.00 & 100.00 \\
IR.2.2.7 & $42.00^{*}$ & 133.33 & 0.00 & 100.00 & 0.00 & 100.00 \\
IR.2.2.5 & 26.50 & 47.22 & 60.00 & 40.00 & 2.75 & 31.25 \\
IR.2.2.6 & 24.25 & 34.72 & 100.00 & 0.00 & 3.20 & 20.00 \\
Control & 18.00 & & 100.00 & & 4.00 & \\
\hline
\end{tabular}

*= no disease symptoms developed until the last day of observations (42 days after pathogen inoculation).

Table 3. Plant height, number of leaves, first day of flowering, and yield of tomatoes

\begin{tabular}{lcccccccc}
\hline Isolates & $\begin{array}{c}\text { Plant } \\
\text { height } \\
(\mathrm{cm})\end{array}$ & $\begin{array}{c}\text { Effective- } \\
\text { ness } \\
(\%)\end{array}$ & $\begin{array}{c}\text { no. of } \\
\text { leaves }\end{array}$ & $\begin{array}{c}\text { Effective- } \\
\text { ness } \\
(\%)\end{array}$ & $\begin{array}{c}\text { First day } \\
\text { of } \\
\text { flowering }\end{array}$ & $\begin{array}{c}\text { Effective- } \\
\text { ness } \\
(\%)\end{array}$ & $\begin{array}{c}\text { Yields } \\
(\mathrm{kg})\end{array}$ & $\begin{array}{c}\text { Effective- } \\
\text { ness } \\
(\%)\end{array}$ \\
\hline IR.2.3.5 & $102.70 \mathrm{a}$ & 47.13 & $51.00 \mathrm{a}$ & 17.51 & $37.00 \mathrm{ab}$ & 9.76 & $1.8307 \mathrm{a}$ & 81.25 \\
IR.1.3.4 & $97.10 \mathrm{ab}$ & 39.11 & $43.60 \mathrm{bc}$ & 0.46 & $45.8 \mathrm{~d}$ & -11.71 & $1.7041 \mathrm{a}$ & 68.72 \\
IR.3.1.4 & $107.60 \mathrm{a}$ & 54.15 & $46.2 \mathrm{~b}$ & 6.45 & $39.80 \mathrm{~b}$ & 2.93 & $1.5423 \mathrm{ab}$ & 52.70 \\
IR.2.2.1 & $90.40 \mathrm{~b}$ & 29.51 & $41.20 \mathrm{c}$ & -5.07 & $39.60 \mathrm{~b}$ & 3.41 & $1.4925 \mathrm{ab}$ & 47.77 \\
IR.2.2.7 & $79.40 \mathrm{c}$ & 13.75 & $41.40 \mathrm{c}$ & -4.61 & $31.00 \mathrm{a}$ & 24.39 & $1.3957 \mathrm{~b}$ & 38.19 \\
IR.2.2.5 & $84.80 \mathrm{~b}$ & 21.49 & $50.80 \mathrm{a}$ & 17.05 & $44.4 \mathrm{~cd}$ & -8.29 & $1.252 \mathrm{bc}$ & 23.96 \\
Control & $69.60 \mathrm{~d}$ & & $43.40 \mathrm{bc}$ & & $41.00 \mathrm{c}$ & & $1.01 \mathrm{c}$ & \\
IR.2.2.6 & $76.40 \mathrm{c}$ & 9.45 & $46.00 \mathrm{~b}$ & 5.99 & $39.60 \mathrm{~b}$ & 3.41 & $0.00 \mathrm{~d}$ & \\
\hline
\end{tabular}

Note: Means with the same letter at the same column are not significantly different by Duncan multiple range test at $p<0.05$ 
agents would effectively prevent the soil-borne plant pathogen such as $R$. syzigii subsp. indonesiensis from attaching to the infection site and proceeding further into the vascular tissue. Additionally, antagonistic action of the biocontrol agents may also play an important role when increased numbers of bacteria are present in the soil or rhizosphere. Applying these agents after transplanting may further increase the effectiveness of biological control. These bacterial agents might be inducing systemic resistance (ISR) or antagonism against $R$. syzigii subsp. indonesiensis.

Our sudies showed that 7 selected isolates had the best biocontrol activity with no wilt symptom appeared. In this study the mechanism of the isolates in controlling R.syzigii subsp. indonesiensis can not be determined. From the results of the in planta screening, however, it can be assumed that the mechanism was indirect mechanism such as Induced Systemic Resistance (ISR). According to Kloepper et al. (1999), ISR could be one of the most important mechanisms against systemic pathogens such as $R$. solanacearum. Other studies had reported that ISR can be triggered by inoculation of bacteria (van Peer et al., 1991; Benhamou et al., 1996; Wilhelm et al., 1998). To characterize all bacterial activity in inducing systemic resistance of tomato plants requires further studies. Host resistance to pathogens could be enhanced by plant activators. In all experiments conducted throughout this study, only a bacterial wilt-susceptible cultivar of tomato was used. In this study we observed that under high $R$. syzigii subsp. indonesiensis inoculum conditions, the IRB introduction were effective in reducing bacterial wilt disease incidence and disease development.

PGPR produce phytohormones that are believed to be related to their ability to stimulate plant growth (Reddy, 2014). The ability of Rhizobacteria isolates to promote plant growth have been widely reported. Swain et al. (2007) found that sweet potato plants (Dioscorea rotundata) which were inoculated with IAA producer Bacillus subtilis significantly increased root growth, stem/root ratio, and height compared to uninoculated plants. The results of this research were similar to Joo et al. (2005), Park et al., (2009) and Battacharyya \& Jha (2012) which stated that the ability of rhizobacteria as growth promoter was indicated by their ability to provide and mobilize nutrions uptake in soil and synthetize and change concentration of pythohormones as growth inducer.

A large number of PGPR were reported to promote plant growth and to control plant diseases (Bashan \& de Bashan, 2002). Yanti et al. (2017), also showed isolates that could control $R$. solanacearum without any symptoms appear. The study of Baharuddin et al. (2005) explained that Pseudomonas spp. fluorescent group in plant rooting was able to colonize well so that it could suppress the attack by R. solanacearum. Sreeja \& Gopal (2013) also found that endophytic actinomycetes isolates from tomato had ability to inhibit growth of $R$. solanacearum and promote growth rate of tomato.

\section{CONCLUSION}

This study had screened potential indigenous rhizobacteria that can promote growth and yields of tomato and also control $R$. syzigii subsp. indonesiensis. Isolates of IR2.3.5, IR1.3.4 and IR1.4.2 were the best isolates in controlling $R$. syzigii subsp. indonesiensis and increasing the growth rate and yield of tomato. Some of their abilities had known such as IAA production and phosphate solubilizing, however, further research need to conduct to identify thus isolates and study more of their mechanisms to promote growth, yields and control pathogens.

Table 4. Characters of selected IRB as biofertilizer.

\begin{tabular}{ccc}
\hline & \multicolumn{2}{c}{ Characteristics as biofertilizer } \\
\cline { 2 - 3 } Isolates & IAA Production $(\mathrm{ppm})$ & Phosphate solubilizing \\
\hline IR.2.3.5 & 32.54 & + \\
IR. 1.3 .4 & 29.52 & + \\
IR.3.1.4 & 24.35 & - \\
IR.2.2.1 & 22.10 & - \\
IR.2.2.7 & 26.75 & - \\
IR.2.2.5 & 29.52 & - \\
IR.2.2.6 & 18.70 & - \\
\hline
\end{tabular}




\section{ACKNOWLEDGMENTS}

This research was funded by Universitas Andalas from research grant "Penelitian Dasar Unggulan Klaster Riset-Publikasi Percepatan Ke Guru Besar Universitas Andalas (KRP2GB-PDU-Unand) 2018".

\section{REFERENCES}

Ahmad F, Ahmad I, \& Khan MS. 2006. Screening of free-living rhizospheric bacteria for their multiple plant growth promoting activities. Microbiol. Res. 163(2): 173-181.

Anith, KN, Momol MT, Kloepper JW, Marois JJ, Olson SM, \& Jones JB. 2004. Efficacy of plant growthpromoting rhizobacteria, acibenzolar-S-methyl, and soil amendment for integrated management of bacterial wilt on tomato. Plant Dis. 88(6): 669-673.

Anuratha CS \& Gnanamanickam SS. 1990. Biological control of bacterial wilt caused by Pseudomonas solanacearum in India with antagonistic bacteria. Plant Soil. 124(1): 109-116.

Baharuddin, Nursaba, \& Kuswinanti T. 2005. Impacts of giving Pseudomonas fluorescens and effective organism in Hampering wilt disease bacterium (Ralstonia solanacearum) in chilli (Capsicum annum L.). In: Sukartiko AC, Nuringtyas TR, Marliana SN, \& Isnansetyo A (Eds.). Scientific Seminar and Annual Meeting of PEI and PFI XVI Komda South Sulawesi. pp. 195-200. South Sulawesi, Indonesia.

Bashan Y \& de-Bashan LE. 2002. Protection of tomato seedlings from the infection by Pseudomonas syringae pv. Tomato by using plant growth promoting bacterium Azospirillum brasilense. Appl Environ Microbiol 68(6): 2637-2643.

Benhamou N, Kloepper JW, Quadt-Hallman A, \& Tuzun S. 1996. Induction of defense-related ultrastructural modifications in pea root tissues inoculated with endophytic bacteria. Plant Physiol. 112(3): 919-929.

Bloemberg GV \& Lugtenberg BJJ. 2001. Molecular basis of plant growth promotion and biocontrol by rhizobacteria. Curr. Opin. Plant. Biol. 4(4): $343-350$
Bowen GD \& Rovira AD. 1999. The rhizosphere and its management to improve plant growth. $A d v$. Agron. 66: 1-102.

Battacharyya \& Jha. 2012. Co-inoculation of soybean with Bradyrhizobium and Azospirillum promotes early nodulation. World Journal of Microbiology and Biotechnology. 28: 1327-1350.

Cook RJ. 1993. Making greater use of introduced microorganisms for biological control of plant pathogens. Annu. Rev. Phytopathol. 31: 53-80.

Dunne C, Crowley JJ, Moenne-Loccoz Y, Dowling DN, de Bruijn FJ, \& O'Gara F. 1997. Biological control of Pythium ultimum by Stenotrophomonas maltophilia W81 is mediated by an extracellular proteolytic activity. Microbiology. 143: 39213931.

Falcón-Rodríguez AB, Cabrera JC, Ortega E, \& Martínez-Téllez MA. 2009. Concentration and physicochemical properties of chitosan derivatives determine the induction of defense responses in roots and leaves of tobacco (Nicotiana tabacum) plants. Am. J. Agric. Biol. Sci. 4(3): 192-200.

Fry SC. 1987. Intercellular feruloylation of pectic polysaccharides. Planta. 171(2): 205-211.

Gamliel A \& Katan J. 1993. Suppression of major and minor pathogens by fuorescent pseudomonads in solarized soil and nonsolarized soils. Phytopathology. 83(1): 68-75.

Hayward AC. 1985. Bacterial wilt caused by Pseudomonas solanacearum in Asia and Australia: an overview. In: Persey GJ (Ed.). Bacterial wilt disease in Asia and the South Pacific: Proceedings of an International Workshop. pp. 15-24. Philippine Council for Agriculture and Resources Research and Development (PCARRD). Los Banos. Philippines.

Joo GJ, King YM, Kim JT, Rhee IK, Kim JH, \& Lee IJ. 2005. Gibberellins-producing rhizobacteria increase endogenous gibberellins content and promote growth of red peppers. J. microbiol. 43(6): 510-515.

Kelman A \& Person LH. 1961. Strains of Pseudomonas solanacearum differing in pathogenicity to tobacco and peanut. Phytopathology. 51: 15862 . 
Kloepper JW, Rodriguez-Kabana R, Zehnder GW, Murphy JF, Sikora E, \& Fernandez C. 1999. Plant root-bacterial interactions in biological control of soilborne diseases and potential extension to systemic and foliar diseases. Australas. Plant Pathol. 28(1): 21-26.

Kucharek T. 1998. Bacterial Wilt of Row Crops in Florida. Circ-1207. University of Florida, IFAS, Cooperative Extension Service.

Lemessa F \& Zeller W. 2007. Screening rhizobacteria for biological control of Ralstonia solanacearum in Ethiopia. Biol. Control. 42(3): 336-344.

Maji S \& Chakrabartty PK. 2014. Biocontrol of bacterial wilt of tomato caused by Ralstonia solanacearum by isolates of plant growth promoting rhizobacteria. Aust. J. Crop Sci. 8(2): 208-214.

Messiha NAS, van Diepeningen AD, Farag NS, Abdallah SA, Janse JD, \& van Bruggen AHC. 2007. Stenotrophomonas maltophilia: a new potential biocontrol agent of Ralstonias olanacearum, causal agent of potato brown rot. Eur. J. Plant Pathol. 118(3): 211-225.

Park KH, Lee CY, \& Son HJ. 2009. Mechanism of insoluble phosphate solubilization by Pseudomonas fluorescens RAF15 isolated from ginseng rhizosphere and its plant growthpromoting activities. Lett. Appl. Microbiol. 49(2): 222-228.

Patten C \& Glick B. 2002. Role of Pseudomonas putida indoleacetic acid in development of the host plant root system. Appl. Environ. Microb. 68(8): 3795-3801.

Pradhanang PM, Momol MT, Olson SM, \& Jones JB. 2003. Effects of plant essential oils on Ralstonia solanacearum population density and bacterial wilt incidence in tomato. Plant Dis. 87(4): 423427.

Ramamoorthy V \& Samiyappan R. 2001. Induction of defense-related genes in Pseudomonas fluorescens-treated chilli plants in response to infection by Colletotrichum capsici. J. Mycol. Pl. Pathol. 31(2): 146-155.

Rangajaran S, Saleena LM, Vasudevan P, \& Nair S. 2003. Biological suppression of rice diseases by Pseudomonas spp. under saline soil conditions. Plant Soil. 251(1): 73-82.
Reddy PP. 2014. Plant Growth Promoting Rhizobacteria for Horticultural Crop Protection. Springer. India.

Safni I, Cleenwerck I, Vos PD, Fegan M, Sly L, \& Kappler U. 2014. Polyphasic taxonomic revision of the Ralstonia solanacearum species complex: proposal to emend the descriptions of Ralstonia solanacearum and Ralstonia syzygii and reclassify current $R$. syzygii strains as Ralstonia syzygii subsp. syzygii subsp. nov., $R$. solanacearum phylotype IV strains as Ralstonia syzygii subsp. indonesiensis subsp. nov., banana blood disease bacterium strains as Ralstonia syzygii subsp. celebesensis subsp. nov. and $R$. solanacearum phylotype I and III strains as Ralstonia pseudosolanacearum sp. nov. Int. J. Syst. Evol. Micr. 64(9): 3087-3103.

Sreeja SJ \& Gopal KS. 2013. Bio-efficacy of endophytic actinomycetes for plant growth promotion and management of bacterial wilt in tomato. Pest Manag. Hort. Ecosyst. 19(1): 63-66.

Swain MR, Naskar SK, \& Ray RC. 2007. Indole-3acetic acid production and effect on sprouting of yam (Dioscorea rotundata L.) minisetts by Bacillus subtilis isolated from cultureable cowdung microflora. Pol. J. Microbiol. 56(2): $103-110$.

Swanson JK, Yao J, Tans-Kersten J, \& Allen C. 2005. Behavior of Ralstonia solanacearum race 3 biovar 2 during latent and active infection of geranium. Phytopathology. 95(2): 136-143.

Tans-Kersten J, Huang H, \& Allen C. 2001. Ralstonia solanacearum needs motility for invasive virulence on tomato. J. Bacteriol. 183(12): 3597-3605.

van Peer R, Niemann GJ, \& Schippers B. 1991. Induced resistance and phytoalexin accumulation in biological control of Fusarium wilt of carnation by Pseudomonas sp. strain WCS417r. Phytopathology. 81(7): 728-734.

Wahyudi AT, Astuti RP, Widyawati A, Meryandini A, \& Nawangsih AA. 2011. Characterization of Bacillus sp. strains isolated from rhizosphere of soybean plants for their use as potential plant growth for promoting rhizobacteria. J. Microbiol. Antimicrob. 3(2): 34-40. 
Whipps JM. 1997. Developments in biological control of soil borne plant pathogens. Adv. Bot. Res. 26: $1-134$.

Wilhelm E, Arthofer W, Schafleitner R, \& Krebs B. 1998. Bacillus subtilis an endophyte of chestnut (Castanea sativa) as antagonist against chestnut blight (Cryphonectria parasitica). In: Cassells AC (Ed.). Pathogen and Microbial Contamination Management in Micropropagation. Developments in Plant Pathology. Vol 12. Springer, Dordrecht.

Xue QY, Chen Y, Li SM, Chen LF, Ding GC, Guo DW, \& Guo JH. 2009. Evaluation of the strains of Acinetobacter and Enterobacter as potential biocontrol agents against Ralstonia wilt of tomato. Biol. Control. 48(3): 252-258.
Yanti Y, Astuti FF, Habazar T, \& Nasution CR. 2017. Screening of rhizobacteria from rhizosphere of healthy chili to control bacterial wilt disease and to promote growth and yield of chili. Biodiversitas. 18(1): 1-9.

Zehnder GW, Murphy JF, Sikora EJ, \& Kloepper JW. 2001. Application of rhizobacteria for induced resistance. Eur. J. Plant Pathol. 107(1): 39-50. 